\title{
Sciendo INTENSITY OF DANGEROUS PHONES FROM WAVES ON SELECTED OCEANIC ROUTES
}

DOI 10.2478/ntpe-2018-0021

\author{
prof. dr hab. inż. Tadeusz Szelangiewicz \\ dr hab. inż. Katarzyna Żelazny, prof. AM \\ Maritime University of Szczecin, Poland
}

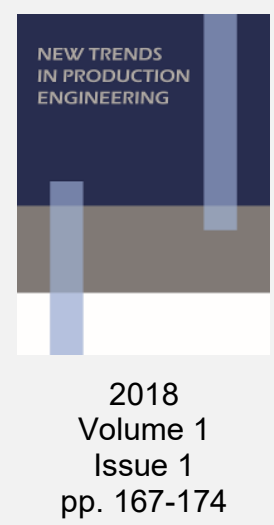

pp. $167-174$

\begin{abstract}
Ocean routes are recommended for ships based on economic criteria. Under the influence of waves. during sailing of the ship. various dangerous phenomena arise which can lead to marine crashes. Although weather sites are known to provide short-term weather forecasts (wave and wind parameters). this information is not used to calculate corrections of ocean-route guidelines. A captain based on his knowledge and experience can make such adjustments. The article presents the results of calculations of the values of dangerous parameters of phenomena which may occur during a cruise on example ocean routes. For the calculation of dangerous phenomena. the average statistical long-term (seasonal) parameters contained in weather atlas were used.
\end{abstract}

Keywords: forecasting ocean routes. irregular long-term (seasonal) waves. dangerous phenomena occurring during sailing at waves

\section{INTRODUCTION}

One of the most important tasks that has a major impact on operating costs is the forecasting of an ocean shipping route when operating a transport ship.

Current forecasting of ocean shipping is conducted according to the following criteria (Wiśniewski, 1991):

- minimizing travel time.

- minimizing fuel consumption.

- minimizing fuel consumption at the assumed time of ship travel.

Various computer programs offered by specialized companies are used to forecast ship navigation. However. despite considerable progress in weather forecasting as well as the ship's sailing route. sea-related crashes caused by wind and wave effects on the flowing vessel continue to be recorded. According to published statistics. the number of crashes is growing (Fig. 1). (Singh, 2014).

The number of emerging crashes is also influenced by lack of full and useful information on the size of safety risks of a sailing vessel. Ocean based forecasting systems use weather data to recommend these routes according to the criteria mentioned. meaning that operational or billing requirements are taken into account. Although these systems have access to forecast weather data. they do not analyze the behaviour of a ship during a cruise. and if there is a potential risk to cargo safety or the entire ship. they do not make corrections to the recommended shipping route. There are also no clear criteria for assessing when the intensity of a dangerous phenomena from waves is a threat to the ship that could lead to a sea crash.

The article presents the results of the calculation of dangerous parameters of the phenomena that occur during the sailing of the ship after the waves is corrugated. The calculations were chosen:

- these phenomena. which are most frequently mentioned in the literature and for which the relevant criteria have been defined (Ghaemi, M. H. and Olszewski, H. 2017, Karppinen, 1997). 
- examples of ocean shipping routes between Europe and North America on which transport vessels.

- and calculations were made for the sample transport vessel and for the statistical mean longterm (seasonal) weather conditions. (Hogben et al. 1986).

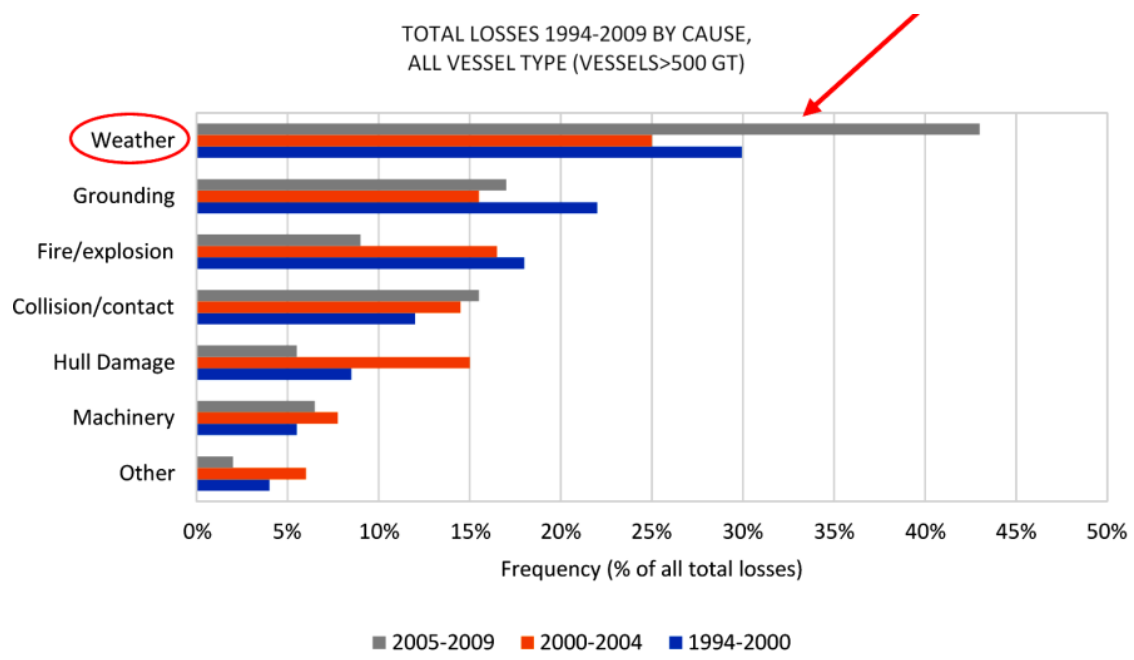

Fig. 1. Statistics on the causes of marine disasters.

Source: own elaboration based on (Singh, 2014)

\section{DANGEROUS PHENOMENA OCCURRING WHEN THE SHIP SAILING AT WAVES}

During the cruise of the ship on the ocean route. waves are cause of motions and many different dangerous phenomena. which at high intensity can cause sea crashes. If the intensity of dangerous phenomena exceeds the permissible criteria. then the course of the ship relative to the wave changes and/or the speed of the ship is reduced.

Table 1.

Criteria for selected seakeeping.

\begin{tabular}{|c|c|c|c|}
\hline & $\begin{array}{c}\text { Merchant } \\
\text { vessels }\end{array}$ & Warships & $\begin{array}{c}\text { Fast small } \\
\text { units }\end{array}$ \\
\hline Vertical accelerations at the bow (RMSD) & $\begin{array}{c}0.275 \mathrm{~g} \text { small } \\
0.1 \mathrm{~g} \text { large }\end{array}$ & $0.275 \mathrm{~g}$ & $0.65 \mathrm{~g}$ \\
\hline Vertical acceleration in the bridge (RMSD) & $0.15 \mathrm{~g}$ & $0.2 \mathrm{~g}$ & $0.275 \mathrm{~g}$ \\
\hline Horizontal lateral acceleration in the bridge (RMSD) & $0.12 \mathrm{~g}$ & $0.1 \mathrm{~g}$ & $0.1 \mathrm{~g}$ \\
\hline Rolling (RMSD) & 6.0 & 4.0 & $4.0^{\circ}$ \\
\hline $\begin{array}{l}\text { Slamming } \\
\text { - probability of occurrence for } 100 \text { waves } \\
\text { - number per hour }\end{array}$ & $\begin{array}{l}0.03 \text { small } \\
0.01 \text { large } \\
20\end{array}$ & 0.03 & 0.03 \\
\hline $\begin{array}{l}\text { Flooding the deck } \\
\text { - probability of occurrence for } 100 \text { waves } \\
\text { - number per hour }\end{array}$ & $\begin{array}{c}0.05 \\
30\end{array}$ & 0.05 & 0.05 \\
\hline
\end{tabular}

Source: (Karppinen. 1987).

The most commonly taken account of the wave behaviour of the ship is considered (Girtler et al. 1995, Karppinen 1997, Lloyd 1989, Mudronja et al. 2015, Prpic-Orsic et al. 2016, Szelangiewicz 1999):

- rolling.

- pitching.

- vertical acceleration.

- transverse horizontal acceleration.

- flooding of the deck.

- slamming.

- emergence of the propeller. 
The criteria set out in Table 1 are used to assess the intensity of dangerous phenomena caused by waves.

Marine properties that have the greatest impact on vessel safety (Table 1) are calculated for the points shown in Figure 2.

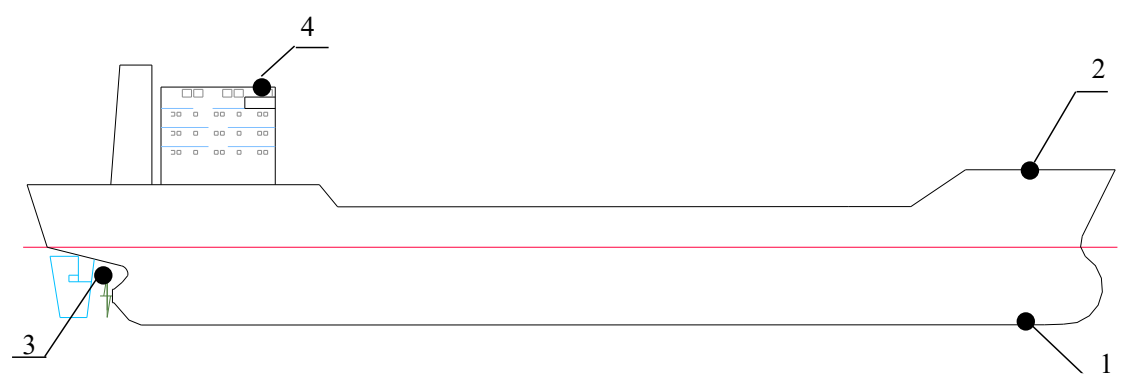

Fig. 2. Points for which seakeeping parameters have been calculated 1 - slamming, 2 - deck flooding and bow accelerations, 3 - propeller emergence, 4 - accelerations in the bridge.

Examples of calculated of seakeeping for a container ship $(L=140.14 \mathrm{~m} . B=22.3 \mathrm{~m} . T=8.25$ $\mathrm{m} . D=1729 \mathrm{~m}^{3}$ ) for different speeds V. Fig. 3.
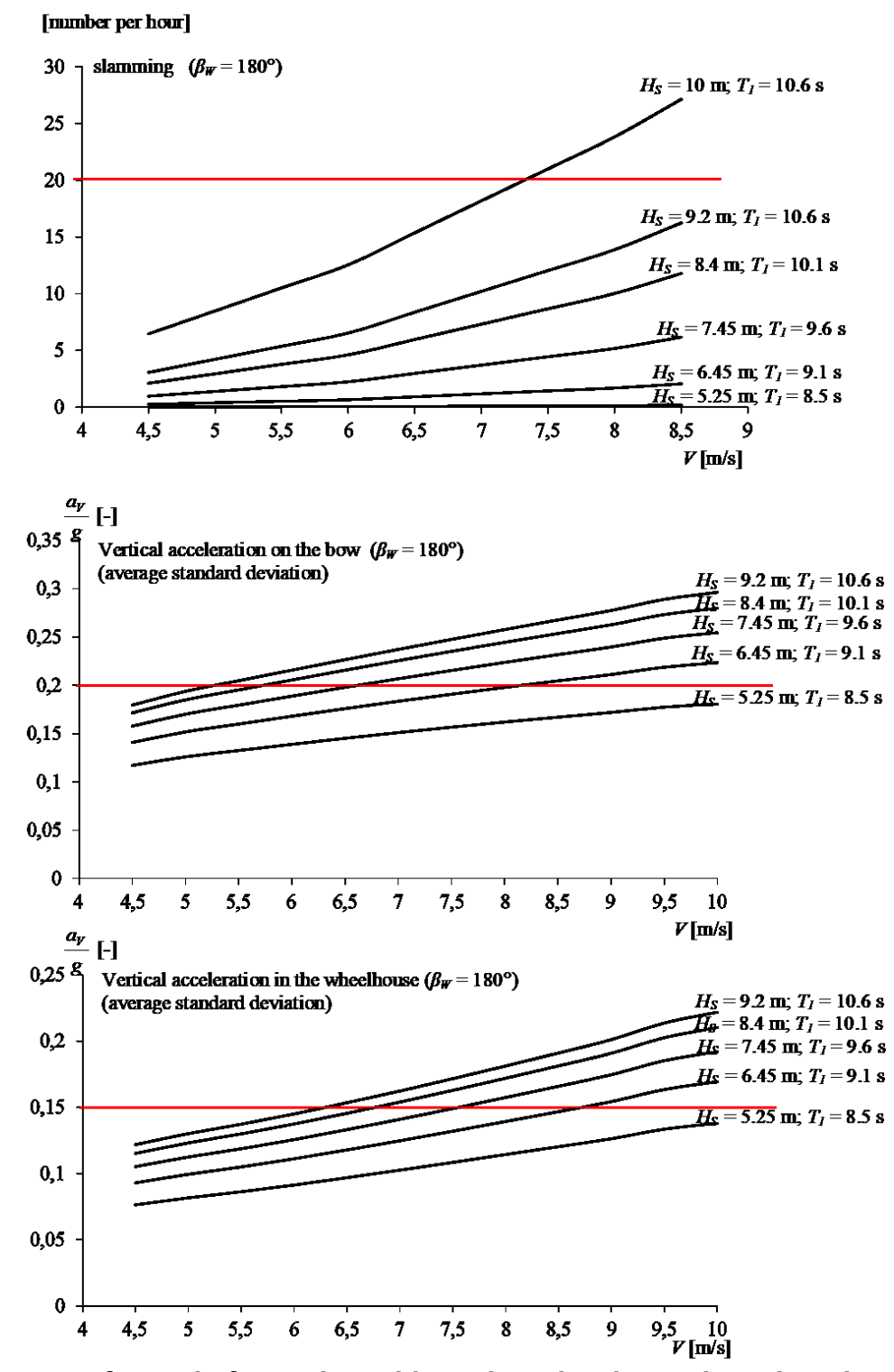

Fig. 3. Influence of speed of container ship and sea level on selected marine properties. 


\section{ANALYZED OCEAN ROUTES AND WEATHER PARAMETERS}

For the calculation of the parameters of dangerous parameters phenomena were selected exemplary of actual ocean routes. Fig. 4. after which vessels sail between Europe and North America.

Calculation of the parameters of dangerous phenomena was made for average statistical parameters (seasonal) recorded in the waters aeras which run analyzed ocean routes. Fig. 4. For these areas. the weather parameters are included in the atlas (Hogben et al. 1986). Sample weather data (wave probability) is shown in Table 2.

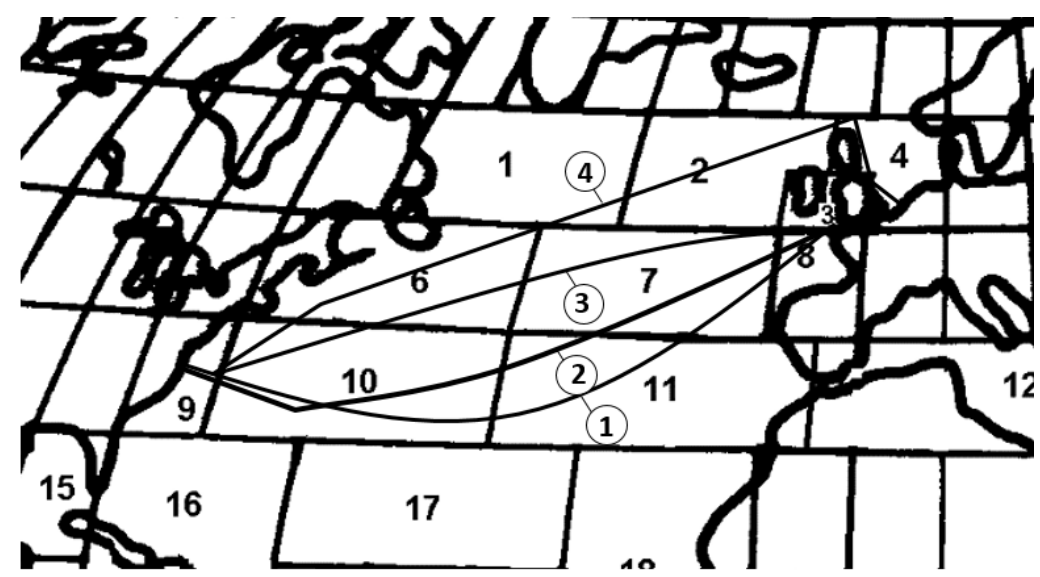

Fig. 4. Examples of ocean routes that vessels sail between Europe and the USA.

Table 2.

Probability of occurrence of wave height HS and period T1 for a given direction at a given water area. Fig. 4.

\begin{tabular}{|c|c|c|c|c|c|c|c|c|c|c|c|}
\hline \multicolumn{12}{|c|}{ Water area: 10} \\
\hline \multicolumn{12}{|c|}{ Season of the year: all year } \\
\hline \multicolumn{12}{|c|}{ Direction of waves: $\mu=240^{\circ}$} \\
\hline Ins] & calm & $<5$ & $6-7$ & $8-9$ & $10-11$ & $12-13$ & $14-15$ & $16-17$ & $18-19$ & $20-21$ & $>21$ \\
\hline 0.25 & & 0.093 & 0.071 & 0.059 & 0.133 & 0.200 & & & & 0.066 & 0.050 \\
\hline 0.5 & & 0.082 & 0.095 & 0.139 & 0.143 & 0.058 & & 0.142 & & 0.428 & 0.060 \\
\hline 1.0 & & 0.094 & 0.088 & 0.101 & 0.109 & 0.125 & & 0.058 & & 0.111 & 0.190 \\
\hline 1.5 & & 0.090 & 0.109 & 0.124 & 0.068 & 0.133 & & & & & \\
\hline 2.0 & & 0.102 & 0.105 & 0.137 & 0.123 & 0.128 & 0.081 & 0.091 & & & \\
\hline 2.5 & & 0.137 & 0.129 & 0.147 & 0.151 & 0.109 & 0.119 & 0.210 & & & \\
\hline 3.0 & & 0.125 & 0.131 & 0.155 & 0.124 & 0.161 & 0.225 & 0.261 & & & \\
\hline 3.5 & & 0.147 & 0.153 & 0.195 & 0.192 & 0.189 & 0.151 & 0.117 & & & \\
\hline 4.0 & & 0.316 & 0.203 & 0.234 & 0.188 & 0.160 & 0.246 & 0.157 & 0.500 & & \\
\hline 4.5 & & 0.273 & 0.257 & 0.160 & 0.154 & 0.155 & 0.236 & 0.310 & 0.062 & 0.500 & \\
\hline 5.0 & & & 0.091 & 0.271 & 0.228 & 0.175 & 0.307 & & & & \\
\hline 5.5 & & 0.333 & 0.286 & 0.158 & 0.182 & 0.142 & & & & & \\
\hline 6.0 & & 0.333 & 0.207 & 0.254 & 0.223 & 0.142 & 0.200 & 0.166 & & & \\
\hline 6.5 & & & 0.261 & 0.240 & 0.272 & 0.231 & 0.091 & 0.500 & & 0.500 & \\
\hline 7.0 & & & 0.333 & 0.143 & 0.368 & 0.500 & 0.166 & 0.333 & & & \\
\hline 7.5 & & & & 0.188 & 0.111 & 0.444 & & 0.166 & & & \\
\hline 8.0 & & & & 0.333 & 0.091 & 0.375 & 0.666 & 0.500 & & & \\
\hline 8.5 & & 1.000 & & & 0.176 & & & 0.500 & & & \\
\hline 9.0 & & & & 0.500 & 0.461 & & 0.200 & & & & \\
\hline 9.5 & & & 0.250 & 0.142 & 0.312 & 0.333 & & & & 0.500 & \\
\hline
\end{tabular}

Source: (Hogben et al. 1986) 


\section{CALCULATION RESULTS}

Calculation of the parameters of the parameters of dangerous phenomena was made for the container ship for individual parts of the ocean routes (Fig. 4) and average statistical. long-term (seasonal) weather parameters (Hogben et al. 1986). The calculation results for each oceanic route (Fig. 4) are shown in Figures 5 and 6. and detailed examples are given in Table 3.
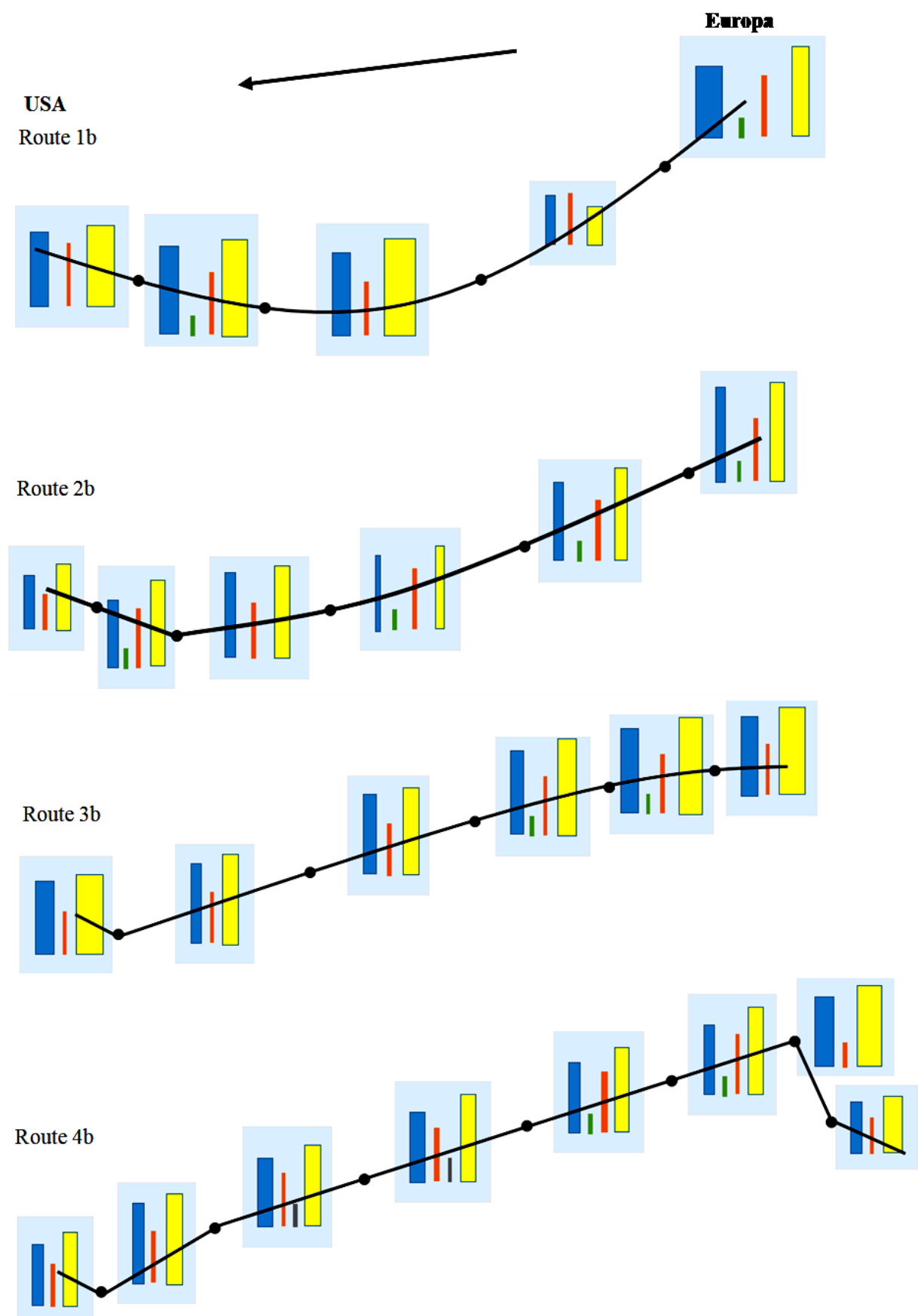

Explanations: Pole height - multiple of the criterion exceed for the max value that occurred on a s section of the route; Bar width - probability of exceeding the value of the safety crit on a given section of the route rolling slamming emergence of the propeller flooding of the deck

transverse horizontal acceleration in the bridg

Fig. 5. Graphical representation of the values of parameters of dangerous phenomena on particular sections of selected ocean routes - Routes from Europe to USA. 

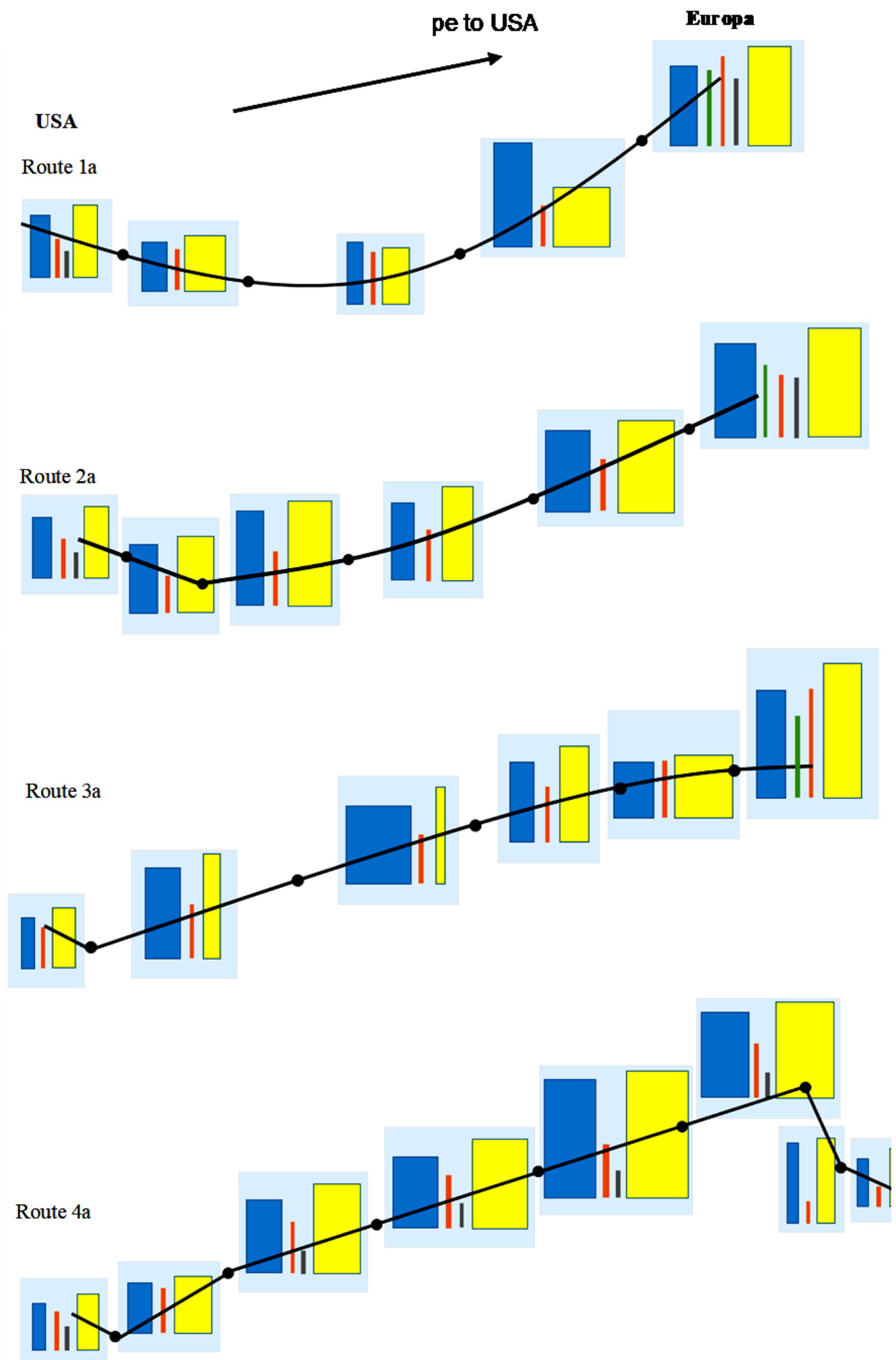

Explanations: Pole height - multiple of the criterion exceed for the max value that occurred on section of the route; Bar width - probability of exceeding the value of the safety on a given section of the route

rolling

slamming

emergence of the propeller

$\square$

flooding of the deck

transverse horizontal acceleration in the b।

Fig. 6. Graphical representation of the values of parameters of dangerous phenomena on particular sections of selected ocean routes - Routes from USA to Europe. 
Table 3.

Results of calculation of parameters of dangerous parameters of phenomena on selected ocean routes from Europe to USA.

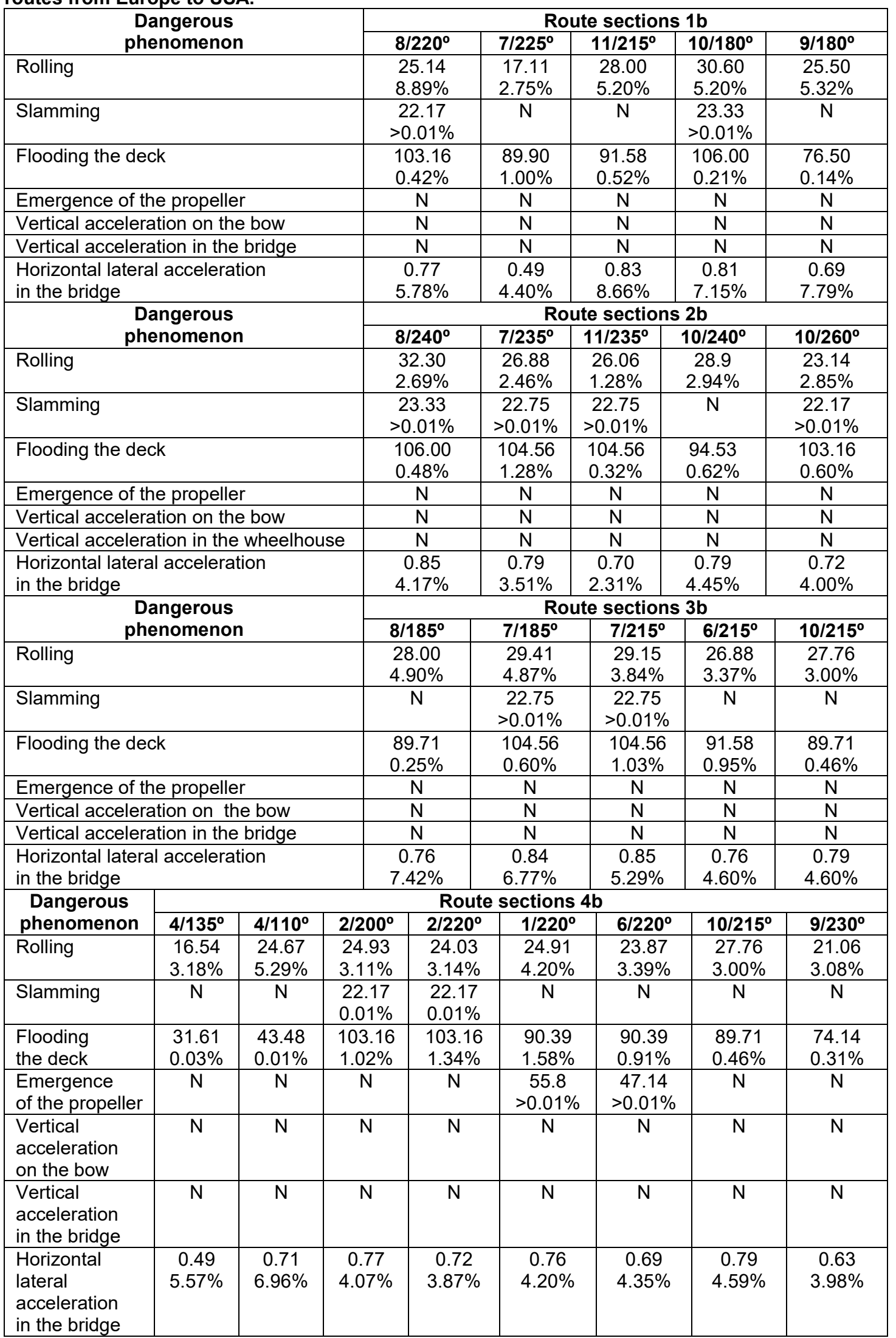

Explanation

Section 8/240: 8 - water area (Fig. 4). $240^{\circ}$ - ship course

Hazardous phenomena. eg. rolling 25.11/8.89\%: $25.14^{\circ}$ - maximum mean standard deviation (Table 1 ).

$8.89 \%$ - probability of exceeding the criterion in Table 1.

$\mathrm{N}$ - no criterion for dangerous occurrence 


\section{CONCLUSIONS}

- Calculation of the parameters of dangerous parameters that may occur on ocean shipping routes was made for average statistical. long-term (seasonal) weather conditions (these are not instantaneous weather conditions that occur during the sailing of the ship).

- Parameters of dangerous phenomena were calculated for individual sections of selected shipping routes.

- The results of the calculation show that the intensity of the resulting dangerous phenomena is different:

a) on individual routes between Europe and the USA.

b) on a given shipping line during a European trip to the USA and a return trip from the USA to Europe.

- For average (seasonal) weather conditions. the intensity of dangerous phenomena for a given shipping line is lower during a US-Europe trip than from Europe to the USA.

- Comparing the results of the calculations. it can be seen that there are shipping lines where the transgression criteria are the smallest. but when cruising from Europe to the USA and vice versa. these will be different shipping lines.

- The calculations show that the values of dangerous phenomena may exceed the criteria and that. in order to limit their impact on the safety of the ship. adjustments to the forecasted shipping routes (change of course and/or change of ship speed).

\section{REFERENCES}

Ghaemi, M. H. and Olszewski, H. (2017). Total ship operability - review, concept and criteria. Polish maritime research, 24(1), pp. 74-81.

Girtler, J., Kitowski, Z. and Kuriata, A. (1995). Bezpieczeństwo okrętu na morzu. Warszawa: Wydawnictwo Komunikacji i Łączności.

Hogben, N. Dacunha, N.M.C. and Olliver, G.F. (1986). Global Wave Statistics. London: Published for British Maritime Technology by Unwin Brothers.

Karppinen, T. (1987). Criteria for Seakeeping Performance Predctions. Helsingfors: Technical Research Centre of Finland.

Lloyd, A.R.J.M. (1989). Seakeeping: Ship Behaviour in Rough Weather. Chichester. England: Ellis Horwood Series in Marine Technology.

Mudronja, L., Vidan, P. and Parunov, J. (2015). Review of seakeeping criteria for container ship sustainable speed calculation in rough weather. Maritime technology and engineering, 1 \& 2, pp. 1059-1064.

Prpic-Orsic, J., Faltinsen, O. M. and Parunov, J. (2016). Influence of operability criteria limiting values on ship speed. BRODOGRADNJA, 67(3), pp. 37-58.

Singh, G.K. (2014). Weather routing and vessel performance monitoring from a charterer's and ship owner's perspective. Singapore: Institute of Chartered Shipbrokers.

Szelangiewicz, T. (1999). Bezpieczeństwo statku podczas pływania w warunkach sztormowych. In: Konferencja: Problemy eksploatacji statków morskich i śródlądowych oraz urządzeń portowych. EXPLO-SHIP'99. Szczecin: Wyższa Szkoła Morska w Szczecinie, 2, pp. 185192.

Szelangiewicz, T. and Żelazny, K. (2013). The influence of the propeller emergence on the torque during sailing of a ship on a regular wave. Scientific Journals of The Maritime University of Szczecin, Zeszyty Naukowe Akademii Morskiej w Szczecinie, 35(107), pp. 138-143.

Wiśniewski, B. (1991). Problemy wyboru drogi morskiej. Gdańsk: Wydawnictwo Morskie. 